\title{
PENGIMPLEMENTASIAN ARTIFICIAL INTELIGENCE PADA SISTEM KEAMANAN LOCKER OTOMATIS BERBASIS SMS GATEWAY DAN RADIO FREQUENCY IDENTIFICATION
}

\author{
Risa Nadia Ernes ${ }^{1)}$, Nanda Tommy Wirawan ${ }^{2)}$, Defnizal ${ }^{3)}$ \\ ${ }^{1}$ Universitas Putra Indonesia "YPTK" Padang, Indonesia \\ ${ }^{2}$ Universitas Putra Indonesia "YPTK" Padang, Indonesia \\ ${ }^{3}$ Universitas Putra Indonesia "YPTK" Padang, Indonesia \\ ${ }^{1}$ risanadiaernes@upiyptk.ac.id \\ ${ }^{2}$ nandatommyw@upiyptk.ac.id \\ ${ }^{3}$ defnizal@upiyptk.ac.id
}

\begin{abstract}
Abstrak
Penelitian ini dilakukan untuk merancang sebuah sistem rotari pada loker dengan menggunakan RFID dan Keypad sebagai input sehingga dapat memberikan keamanan pada loker.Sistem ini dibuat dengan merancang, membuat dan mengimplementasikan komponen-komponen sistem yang meliputi arduino Uno sebagai pengendali proses, RFID sebagai input untuk keamanan menggunakan kartu ID Keypad sebagai setting password berperan sebagai input, dan menggunakan LCD sebagai media untuk tampilan informasi serta penggunaan Motor DC dan Motor Servo Sebagai Penggerak. Hasil penelitian menunjukkan alat yang dibuat dapat berfungsi dengan baik dan dapat dikembangkan untuk skala yang lebih besar.
\end{abstract}

Keywords: Arduino, RFID, Keypad, Sms Gateway

\section{PENDAHULUAN}

Tindakan kriminal berupa pencurian adalah suatu kegiatan yang tidak lepas dalam kehidupan sehari-hari. Peningkatan angka kriminal yang semakin lama semakin meningkat seiring dengan perkembangan teknologi, membuat sistem keamanan yang ada di perkantoran, pendidikan, perumahan, maupun pada kantor bagian arsip menjadi sesuatu yang sangat penting untuk diperhatikan . Keterbatasan sumber daya manusia yang digunakan untuk menjaga keamanan juga menjadi masalah yang dirasa perlu untuk dicarikan solusi , untuk itu perlu suatu alat bantu yang dapat mempermudah dalam pengawasan keamanan tersebut. Penggunaan loker yang biasanya hanya menggunakan kunci manual, sehingga kurangnya keamanan, karena penggunaan kunci manual memiliki banyak kekurangan dalam segi keamanan, salah satu contoh kunci mudah hilang dan besar kemungkinan adanya penggandaan kunci(Duplikat) sehingga keamanan loker menjadi terancam. Penggunaan loker sangat dibutuhkan terutama di perkantoran yang memiliki arsip-arsip penting yang harus dijaga kerahasiaan serta keamanannya.[1]. Seiring dengan semakin berkembangnya kemajuan teknologi terutama di bidang komputerisasi, sehingga sangat memungkinkan untuk menciptakan sistem pengaman loker otomatis dengan menggunakan sistem keamanan penguncian otomatis menggunakan RFID dan Keypad .

Teknologi Radio Frequency Identification (RFID) telah merambah ke berbagai sektor. Dukungan teknologi RFID memungkinkan otomasi layanan ini menuntut adanya sistem rotari pada Locker sehingga mempermudah pemilik untuk menyimpan barang.[2]. 
Dari latar belakang diatas munculah ide serta inovasi untuk membuat sebuah loker otomatis dengan menggunakan sistem keamanan berupa RFID dan keypad yang digunakan untuk sistem penguncian otomatis, serta penggunaan SMS Gateway yang berfungsi untuk sistem monitoring jika terjadi hal-hal yang tidak diinginkan seperti pencurian atau bahkan pembobolan loker.

\section{METODE PENELITIAN}

Kerangka kerja ini merupakan langkah-langkah yang akan dilakukan dalam rangka penyelesaian masalah yang akan dibahas, seperti gambar 1 :

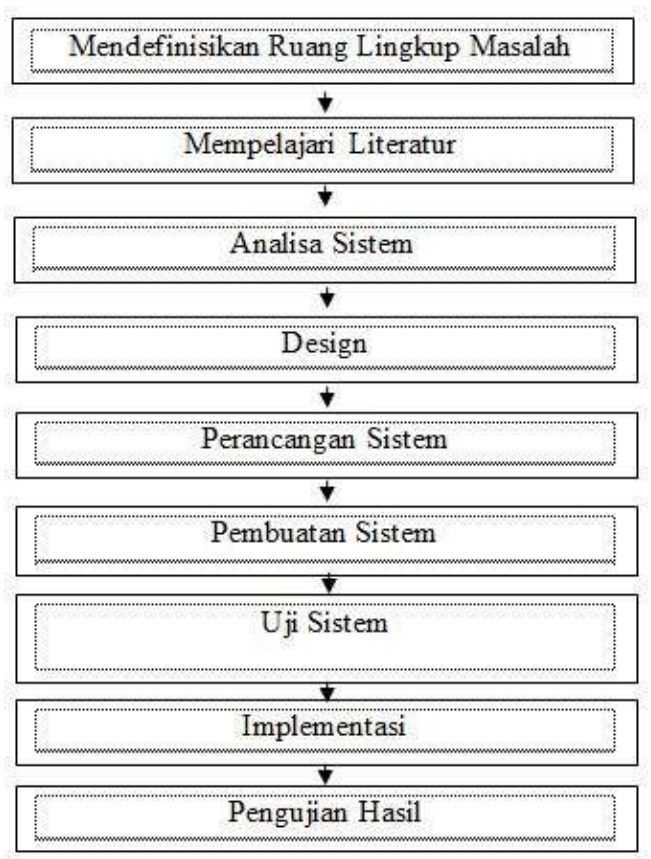

\section{Gambar 1 Metodologi Penelitian}

Berdasarkan kerangka kerja maka masing-masing langkah dapat diuraikan sebagai berikut :

\section{Mendefinisikan Ruang Lingkup Masalah}

Ruang masalah yang akan diteliti harus ditentukan terlebih dahulu, karena tanpa mampu mendefinisikan serta menentukan batasan masalah yang akan diteliti, maka tidak akan didapat suatu solusi yang terbaik dari masalah tersebut.

\section{Mempelajari Literatur}

Untuk mencapai tujuan yang akan ditentukan, maka perlu dipelajari beberapa literatur-literatur yang digunakan. Kemudian literatur-literatur yang dipelajari tersebut diseleksi untuk dapat ditentukan literatur mana yang akan digunakan dalam penelitian. Melalui studi literatur, dipelajari teori-teori yang berhubungan dengan RFID, Sms Gateway, Arduino, dan pengaplikasian teknologi. Sumber literatur berupa buku, jurnal, dan data-data dari situs internet yang sesuai dengan penelitian.

\section{Analisis Sistem}

Pada tahap ini, yaitu menganalisa semua hal yang berkaitan dalam perancangan Sistem Keamanan Loker. Hal yang dianalisa adalah sebagai berikut:
a. Sistem Kemanan Loker yang terintegrasi dengan RFID;
b. Komponen-komponen yang membatu proses kontrol pada sistem keamanan loker;
c. Media interaksi berupa SMS Gateway;
d. Hardware dan Software yang digunakan.

\section{Design Sistem}

Pada tahap desain, ditentukan unsurunsur yang terkandung yang akan dituangkan kedalam flowchart. Flowchart merupakan acuan alur dalam pembuatan sistem keamanan loker.

\section{Perancangan Sistem}

Tahap ini bertujuan untuk merancang sistem yang akan dibuat, seperti:

a.

Rancangan loker; 

b. Rancangan rangkaian elektronik pada sistem keamanan loker;
c. Rancangan program.

\section{Pembuatan Sistem}

Pada tahap ini, yang dibuat adalah:

a. Pembuatan Loker yang dibuat dari bahan dasar Threeplex dan Aluminium dengan ukuran adalah $50 \mathrm{~cm}$ x $50 \mathrm{~cm}$;

b. Pembuatan Sistem Kontrol.

\section{Uji Sistem}

Pada tahap ini, Sistem yang akan diuji adalah:
a. Sistem Keamanan Loker yang sudah terintegrasi RFID ;
b. Output Interaksi Sms Gateway..

Pengujian sistem tersebut menggunakan software Arduino untuk pemrogramannya dengan bantuan alat downloader yang digunakan untuk mengisi program ke dalam mikrokontroler Arduino. Kemudian masing-masing modul diuji apakah berfungsi atau tidak.

\section{Implementasi}

Pada tahapan ini, pengimplementasian Sistem keamanan loker ke RFID dan keypad sebagai kunci otomatis kemudian data akan di proses dan akan dikirimkan ke sistem kontrol supaya mengeluarkan output berupa pintu loker terbuka.

\section{Pengujian Hasil}

Pada tahap ini, yang akan diuji adalah sistem keamanan loker. apakah data yang dibaca pada kartu RFID cocok dengan output yang dikeluarkan oleh sistem.

Yang diuji pada tahap ini adalah:
1. Modul RFID dan Kartu RFID;

2. SMS Gateway.

\section{HASIL DAN PEMBAHASAN}

\section{Rancangan Sistem Secara Umum}

Secara umum bentuk dari perancangan sistem rotari pada loker otomatis ini terdiri atas rangkaian elektronika. Rangkaian elektronika ini berfungsi untuk memberikan data berupa sinyal digital yang akan diproses oleh Arduino Uno sesuai logika program yang dirancang.

Untuk menggambarkan sistem yang akan dibangun ini secara umum, maka sebagaimana aturan didalam proses penganalisaan bahwa perlu dilakukan pendefenisian terlebih dahulu terhadap sistem yang akan dirancang tersebut secara menyeluruh. Artinya bahwa harus ada gambaran secara jelas mengenai ruang lingkup pembahasan dimana sebagai medianya adalah berupa Context Diagram dan Data Flow Diagram.

\section{Context Diagram}

Context Diagram adalah pendefenisian terhadap sistem yang akan dirancang yang bersifat menyeluruh. Context Diagram digunakan untuk memudahkan proses penganalisaan terhadap istem yang dirancang secara keseluruhan.

Dalam hal ini Context Diagram berfungsi sebagai media yang terdiri dari suatu proses dan beberapa buah eksternal entity. Cara sistem bekerja dapat dilihat dari Context Diagram dan dapat dilihat pada gambar 2 


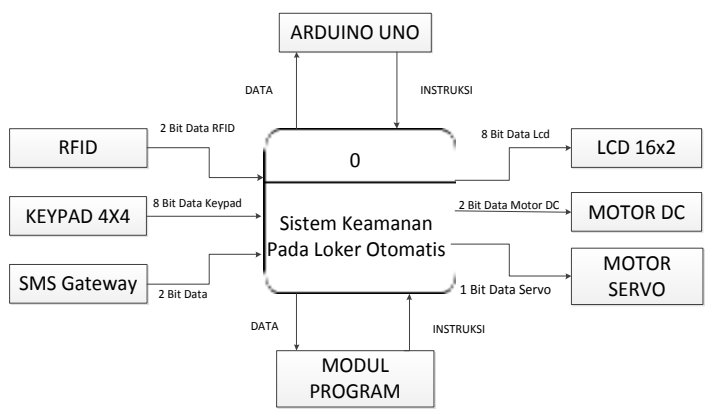

Gambar 2 Context Diagram

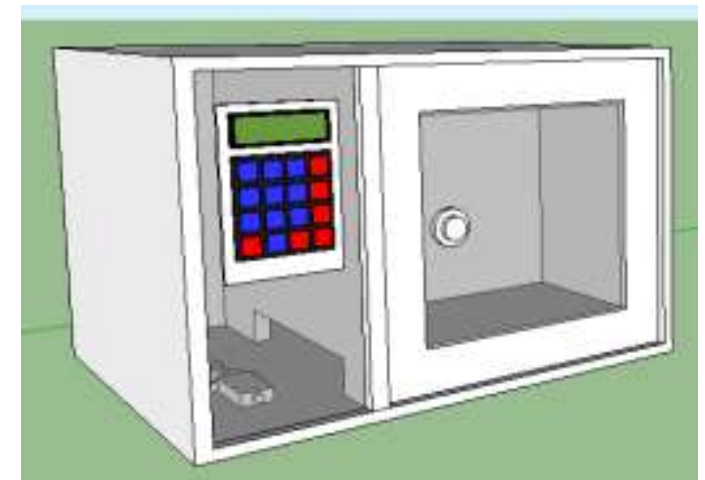

Gambar 4 Rancang Fisik Alat

\section{Data Flow Diagram}

Data Flow Diagram adalah gambaran yang lebih rinci dari alat yang dirancang. Data Flow Diagram ini diuraikan berdasarkan Context Diagram yang telah dijabarkan sebelumnya. Gambar data flow diagram dapat dilihat pada gambar 3 .

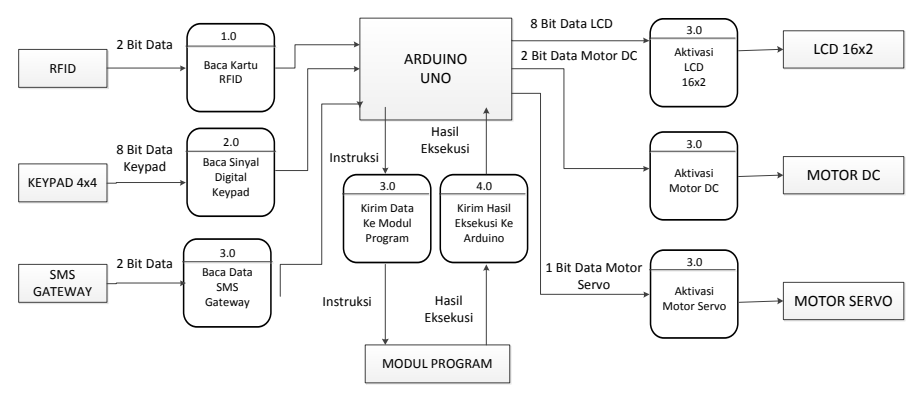

Gambar 2 Data Flow Diagram (DFD) Level 0

\section{Rancangan Fisik Alat}

Perancangan alat ini merupakan tahap awal dari pemasangan dan menganalisa permasalahan yang dihadapi berdasarkan literatur yang menunjang perancangan alat. Berikut adalah gambar rancangan fisik alat :

\section{Desain Secara Terinci}

Desain dari sistem yang dibuat merupakan gambaran dari sistem secara keseluruhan. Dengan adanya desain ini maka prinsip kerja dari sistem serta komponenkomponen dari sistem yang digunakan akan dapat dilihat dengan jelas.

\section{LCD 16x2}

LCD dalam sistem ini digunakan untuk menampilkan box terbuka. Rangkaian LCD dan hubungan dengan arduino ditunjukkan pada gambar 5 .

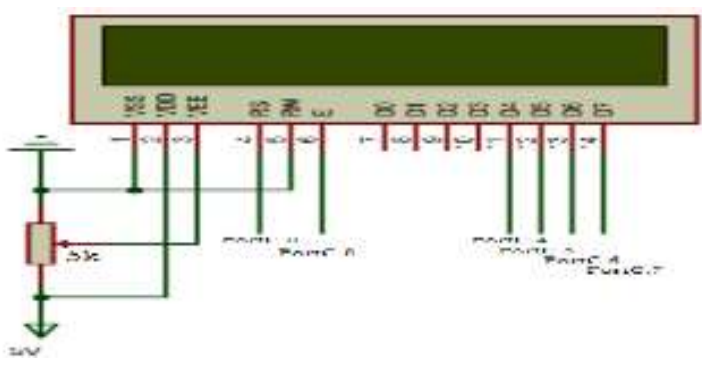

Gambar 5 Rangkaian LCD

\section{Motor DC}

Motor DC Berfungsi sebagai Penggerak Pada Loker sesuai dengan perintah dari arduino uno. Berikut dapat dilihat bentuk dari rangkaian driver motor. 


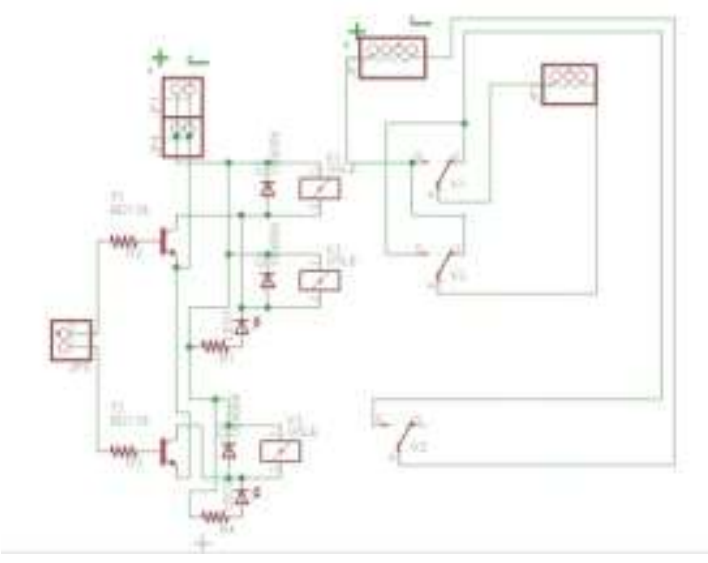

Gambar 6 Rangkaian Motor DC

\section{PENGUJIAN SISTEM}

\section{A. Pengujian RFID ( Kartu "1")}

Setelah sistem aktif, RFID akan mendeteksi kartu berdasarkan ID kartu. Pada sistem ini digunakan 3 buah kartu dengan fungsi berbeda pada setiap kartunya. Apabila ingin membuka box 1 maka gunakan kartu "1", seperti gambar 7.

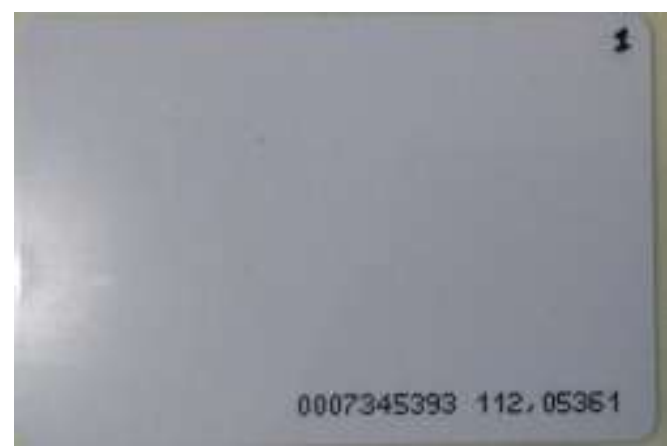

Gambar 7 Kartu RFID “1”

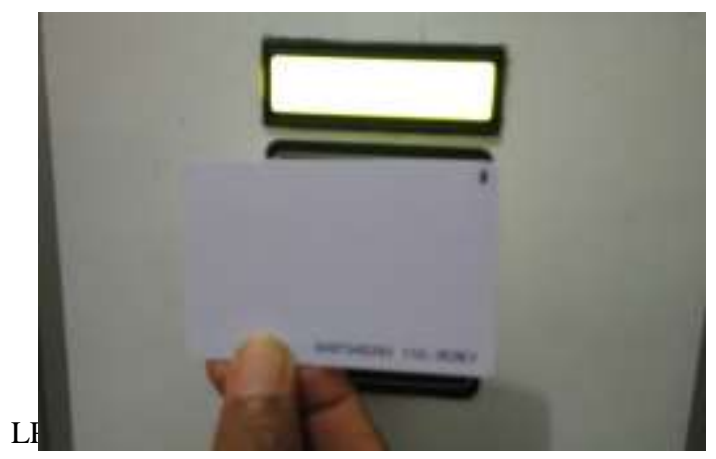

\section{Gambar 8 Pendeteksian Kartu RFID "1"}

Setelah kartu RFID terdeteksi maka sistem akan mulai memproses dan akan tampil pada LCD untu memasukan password. Seperti gambar 9 berikut ini.

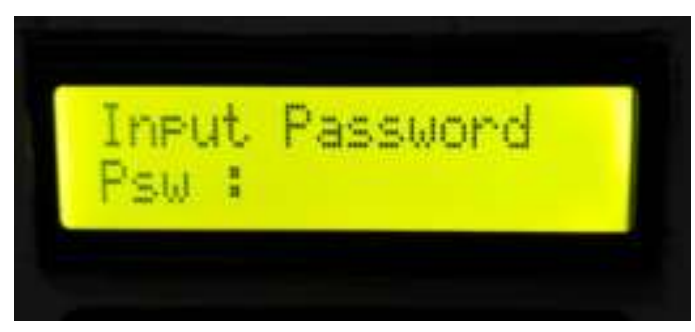

\section{Gambar 9 Tampilan Inputkan Password}

Apabila RFID telah terdeteksi maka silahkan masukkan password sesuai dengan perintah yang telah diatur sebelumnya.

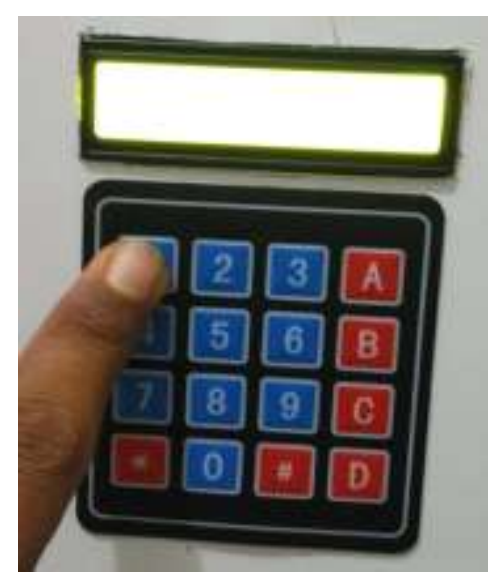

\section{Gambar 10 Setting Password Pada Keypad}

Jika password yang dimasukkan benar, maka sistem akan menampilkan informasi pada LCD dengan tampilan seperti gambar 11 berikut ini. 


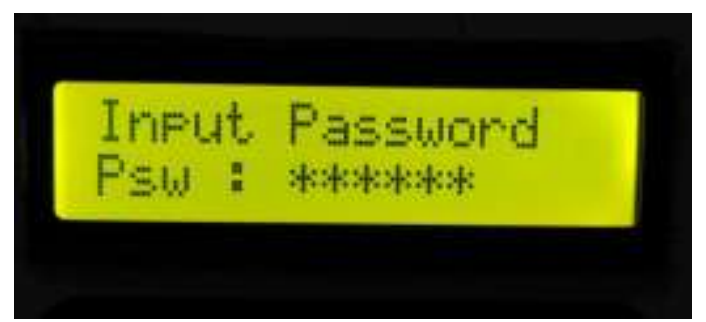

Gambar 11 Tampilan Pengisian Password

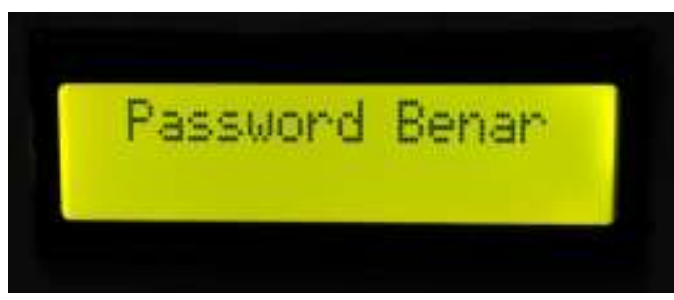

Gambar 12 Tampilan LCD Jika Password Benar

Setelah password yang dimasukkan benar maka akan otomatis box 1 aktif dan pintu akan otomatis terbuka. Seperti gambar 13 berikut ini

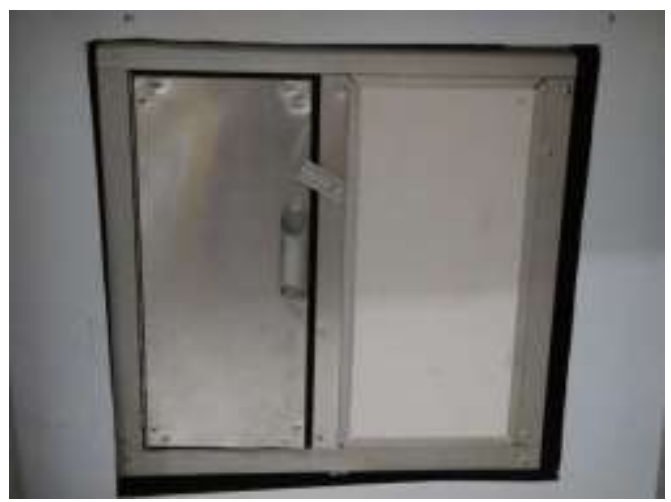

\section{Gambar 13 Posisi Box 1}

Pada posisi ini servo berfungsi sebagai kunci otomatis, jadi setelah box berputar maka secara otomatis pintu juga akan terbuka.

\section{B. Pengujian RFID ( Kartu "2")}

Pada tahap selanjutnya apabila menggunakan kartu RFID 2 maka sistem akan mendeteksi kartu RFID 2. Seperti gambar 14 berikut ini.

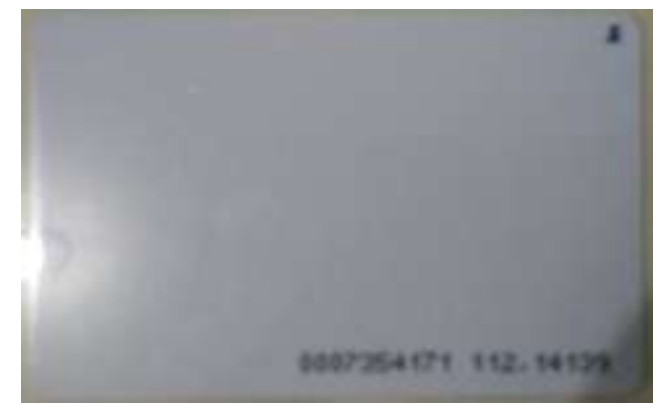

Gambar 14 Kartu RFID 2

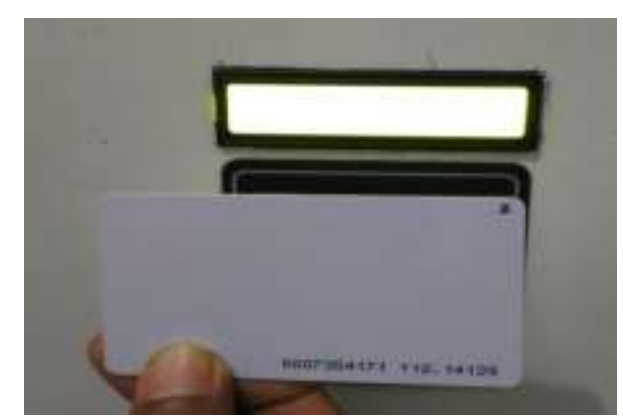

\section{Gambar 15 Pendeteksian Kartu RFID " 2 "'}

Setelah kartu RFID terdeteksi maka sistem akan mulai memproses dan akan tampil pada LCD untuk memasukan password. Seperti gambar 16 berikut ini

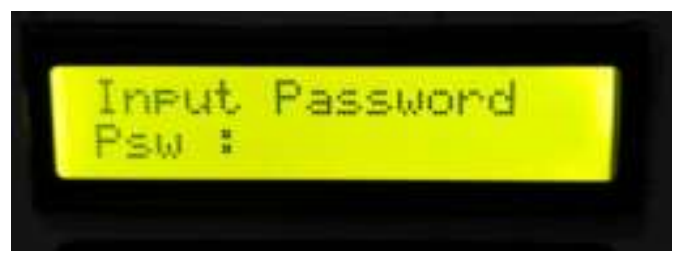

Gambar 16 Tampilan inputkan password 
Apabila RFID telah terdeteksi maka silahkan masukkan password sesuai dengan perintah yang telah diatur sebelumnya.

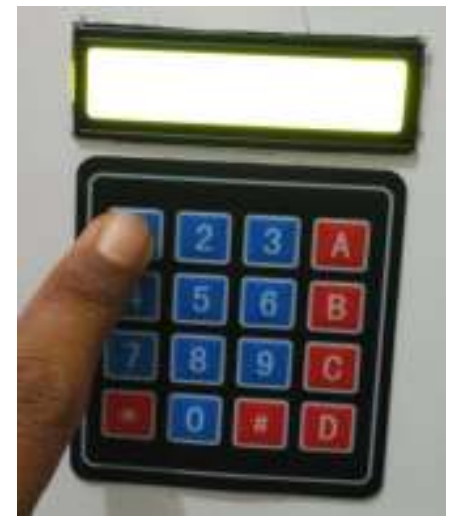

\section{Gambar 17 Setting Password Pada Keypad}

Jika password yang dimasukan benar, maka sistem akan menampilkan informasi pada LCD dengan tampilan seperti gambar 17 berikut ini.

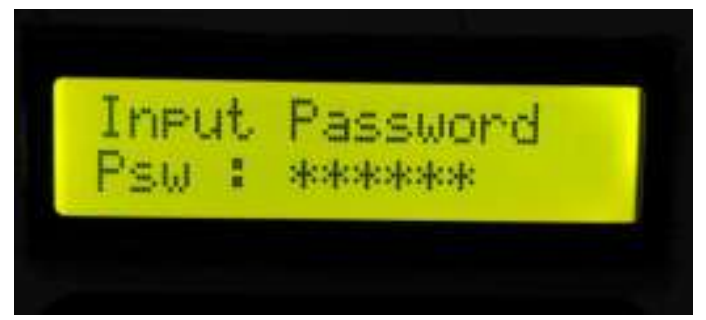

\section{Gambar 17 Tampilan Pengisian Password}

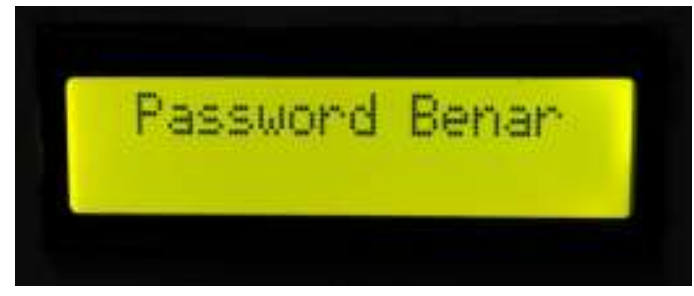

\section{Gambar 18 Tampilan LCD Jika Password Benar}

Setelah password yang dimasukkan benar maka box 2 otomatis berputar dan pintu akan otomatis terbuka. Seperti gambar 19 berikut ini.

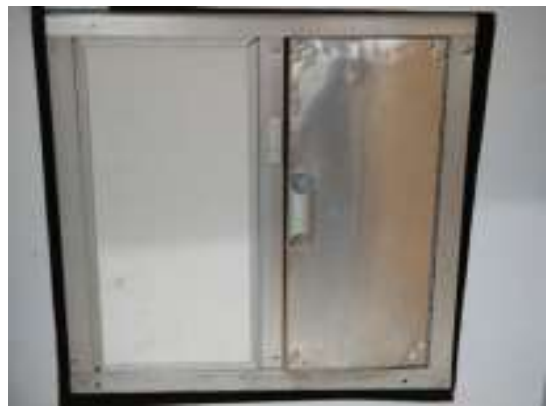

\section{Gambar 19 Posisi Box 2}

Pada posisi ini servo berfungsi sebagai kunci otomatis, jadi setelah box berputar maka secara otomatis pintu juga akan terbuka.

\section{Pengujian RFID ( Kartu “3” )}

Pada tahap akhir ini kartu RFID 3 berfungsi sebagai kartu yang digunakan sebagai kartu yang tidak terdaftar, Maaksudnya adalah sebagai simulasi apabila ada pihak lain yang ingin membobol keamanan loker otomatis ini. Seperti pada gambar 20 berikut ini.

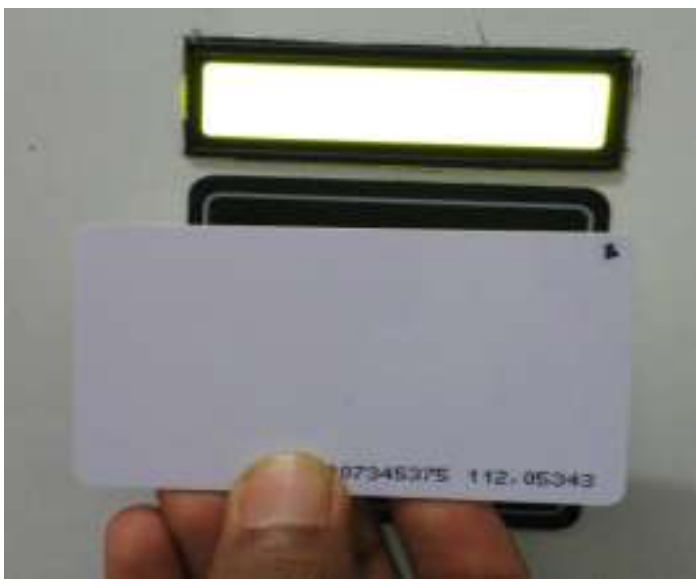

\section{Gambar 20 Pendeteksian Kartu RFID “3”}

Setelah kartu RFID 3 terdeteksi maka sistem akan mulai memproses dan akan tampil pada LCD untuk memasukan password. Seperti gambar 21 berikut ini. 


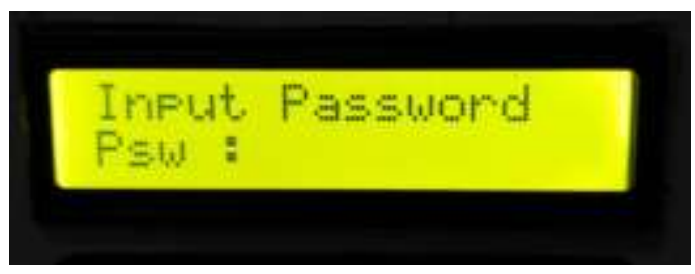

Gambar 21 Tampilan Inputkan Password

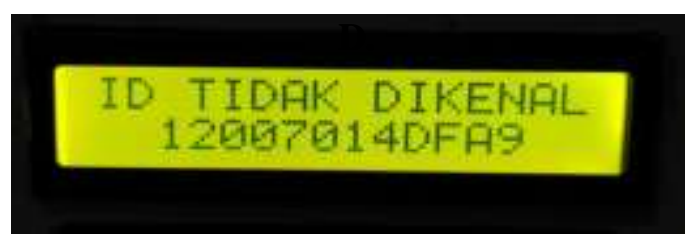

\section{Gambar 22 Tampilan Jika Kartu RFID Tidak Dikenal}

\section{SIMPULAN}

Berdasarkan analisa dari sistem kerja sistem keamanan pada locker ini dapat di ambil suatu kesimpulan bahwa :

1. Dengan dirancang sistem rotari pada locker otomatis maka sistem bisa berjalan sesuai dengan yang diinginkan.

2. Dengan menggunakan Arduino, agar dapat mengontrol kerja sistem yang akan di buat.

3. Penggunaan RFID pada sistem ini mampu memberikan input yang akurat sehingga input tersebut bisa di proses di arduino dengan baik.

4. Dengan menggunakan motor DC sehingga box mampu melakukan perputaran sesuai dengan input pada kartu RFID.
Triyono, A. S. (2017). Bangun Loker Penyimpanan Aset Menggunakan Voice Berbasis Arduino Pada Dinas Marga Dan Pengairan Kabupaten Tangerang. Seminar Nasional Multi Disiplin Ilmu, Vol 1, 283

Nalwan Andi. 2012. Teknik Rancang Bangun Robot. Yogyakarta : Andi.

RFID. (Mei, 2016). Radio Frequency Identification. ttp://thesis.binus.ac.id/ Asli/Bab2/2008-1-00413-SK-Bab\%202.pdf.

Arduino. (February, 2017). SPI Library. https://www.arduino.cc/en/reference/SPI

Elektronika, L. (Mei, 2016). Liquid Crystal Display $\quad 16 \times 2 . \quad$ http://www.lesele ktronika.com/2012/06/liguid-crystal-displaylcd-16-x-2.html.

Wijayanto I,'Pemrograman RTC DS1307 menggunakanCVAVR",http://iwijayanto.staff .telkomuniversity.ac.id/pemrograman-rtcds1307-menggunakan-cv-avr/diakses tanggal 11 April2017.

Rakhmatsyah A,Suwastika N A,Haryanto,R. "Implementasi Sistem Kunci Pintu Otomatis Untuk Smart Home Menggunakan SMS Gateway” ,Jurnal ,Telkom Univercity , 2015

Setyadi R T,Badzlina A., "Perancangan Prototype Sistem Kunci Otomatis Pada Loker Penitipan Barang Komersial", Tugas Akhir, Institut Teknologi Sepuluh Nopember, Surabaya, 2016.

Sri Mulyani. Metode Analisis dan Perancangan Sistem.2016. Bandung. Penerbit Abdi Sistematika.

Muhamad Muslihudin, Oktafianto. Analisis dan Perancangan Sistem Informasi Menggunakan Model Terstruktur dan UML. 2016. Yogyakarta. Penerbit Andi.

\section{DAFTAR PUSTAKA}


Jurnal KomtekInfo , Vol.8 No.1 Tahun 2021

e-ISSN : 2502-8758 || p-ISSN : $2356-0010$ DOI : $10.35134 /$ komtekinfo.v7i4

Page : 57-65 